\title{
Multivariate morphometric analysis of the Apis cerana populations of oceanic Asia
}

\author{
Sarah E. RADLOFF ${ }^{a *}$, H. Randall HEPBURN ${ }^{b}$, Stefan FUCHS ${ }^{\mathrm{c}}$, Gard W. OTIS ${ }^{\mathrm{d}}$, \\ Soesilawati. HADISOESILO ${ }^{\mathrm{e}}$, C. HEPBURN ${ }^{\mathrm{a}}$, Tan $\mathrm{KEN}^{\mathrm{f}}$ \\ ${ }^{\text {a }}$ Department of Statistics, Rhodes University, Grahamstown 6140, South Africa \\ b Department of Zoology and Entomology, Rhodes University, Grahamstown 6140, South Africa \\ ${ }^{c}$ Institut für Bienenkunde, 61440 Oberursel, Germany \\ d Department of Environmental Biology, University of Guelph, Guelph, Ontario N1G 2W1, Canada \\ ${ }^{\mathrm{e}}$ Forest and Nature Conservation Research and Development Centre, Bogor, Indonesia \\ ${ }^{f}$ Eastern Bee Research Institute, Yunnan Agricultural University, Kunming, China
}

Received 2 November 2004 - Revised 10 January 2005 - Accepted 10 January 2005

Published online 9 August 2005

\begin{abstract}
Morphometric analyses of Apis cerana workers from 123 localities in oceanic Asia were made on the whole oceanic group, within specific island systems, and specific mainland-oceanic island "interfaces". Principal component analysis of the total oceanic database yielded two distinct morphoclusters: (1) the bees of Japan and morphocluster and (2) the bees of all the other islands. Discriminant and hierarchical cluster analyses showed overlapping regional clusters in the latter: 2.1 the bees of the Philippines (except Palawan) and some Indonesia, 2.2 bees of Palawan, Malaysian Borneo, Kalimantan, Sumatera and some Sulawesi (Indonesia), and 2.3 most of Indonesia, Papua New Guinea, Hainan (China) and Sri Lanka. Significant differences between the means of the four groups were demonstrated using Wilks' lambda statistic. The Mahalanobis distances among the honeybee samples are consistent with cyclical, geological rises and falls of sea level between present and Pleistocene land areas.
\end{abstract}

Apis cerana / morphometrics / biogeography / islands

\section{INTRODUCTION}

Following the original description of Apis cerana by Fabricius (1793), the next century yielded several historically important papers on the classification of the honeybees of Asia (Smith, 1854-1871, cf. Smith, 1871; Gerstäcker, 1863; Moore et al., 1871; Horne and Smith, 1872). Subsequently, Enderlein (1906) and von Buttel-Reepen (1906) added further interpretations of infraspecific taxa of A. cerana. Taxonomic methods then in use eventually resulted in problems of nomenclature, which were discussed at length by Maa (1953). After the intro- duction of multivariate statistical methods in population analyses of honeybees (DuPraw, 1964), this method was substantially developed by Ruttner et al. (1978, cf. Ruttner et. seq.) and Daly and Balling (1978, cf. Daly et. seq.), and was first applied to A. cerana by Ruttner $(1985,1988)$ and remains the operative analytical method.

In retrospect, analyses of the infraspecific categories of Apis cerana in earlier times were limited by then prevailing methodology in earlier times (Hepburn et al., 2001a); but, more recently, multivariate morphometric studies of the A. cerana of mainland Asia have begun to

\footnotetext{
* Corresponding author: s.radloff@ru.ac.za
} 
clarify their population structure (Ruttner, 1988; Hepburn et al., 2001b; Ken et al., 2003; Radloff et al., 2005a, b). Similarly, the A. cerana of oceanic Asia have recently been characterized using multivariate methods of analysis in regional studies of Sri Lanka (Fernando, 1979; Szabo, 1990), Philippines (Rinderer et al., 1989; Damus, 1995; Damus and Otis, 1997; Tilde et al., 2000), and Indonesia (Sulistianto, 1990; Hadisoesilo et al., 1995; Damus and Otis, 1997). However, with few exceptions (Ruttner, 1985, 1988; Damus and Otis, 1997), there have been no other attempts to perform a consolidated analysis of all oceanic A. cerana on a mesoscale level.

Here, we report the results of morphometric analyses of oceanic Apis cerana. Data representing 123 localities from throughout oceanic Asia were analysed at different levels. A mesoscale analysis was made on the oceanic group alone, then microscale analyses were made within specific island systems at a more discrete population level. The latter analyses included comparisons between Papua New Guinea (Irian Jaya) and Indonesia (Java), $A$. cerana having been introduced to the former from the latter. Finally, analyses of specific mainland-oceanic island "interfaces" such as Sri Lanka - India, Indonesia-Borneo-Philippines - Southeast Asia mainland, Hainan China mainland and Japan - Korea were also made. Until analyses of the A. cerana of northeastern Asia are completed, morphometrically discernible groups reported here are described as "morphoclusters" and not given formal subspecific names because they could not yet be reconciled within the rules of the International Code of Zoological Nomenclature (Engel, 1999).

\section{MATERIALS AND METHODS}

\subsection{Honeybees}

The worker honeybees used for the analyses of oceanic A. cerana derive from: (1) the raw database of the Institut für Bienenkunde at Oberursel, (Oberursel); (2) new data from bees collected from Hainan (China), (Kunming); (3) new data from bees collected in Indonesia, N. Borneo (Malaysia), Papua New Guinea, Philippines and Sri Lanka (Grahamstown); (4) raw data from Hadisoesilo, (Hadisoesilo); (5) raw data from Rinderer et al. (1989), Sulistianto
(1990) and Tilde et al. (2000); (6) processed data from Akahira and Sakagami (1959a, b) and Szabo (1990); (7) additional information based on statistically processed data from Damus and Otis (1997); (8) for comparisons between oceanic and mainland A. cerana, the raw data used for the latter is cited in Radloff et al. (2005b). Collectively, about 5310 honeybees collected from 346 colonies at 123 localities were measured morphometrically and statistically analyzed (Tab. I, Fig. 1).

\subsection{Measurements}

Twelve morphological characters of worker honeybees common to the Ruttner/Oberursel, Kunming, Grahamstown, Rinderer et al. (1989), Sulistianto (1990) and Tilde et al. (2000) databases were utilized. Their Ruttner (1988) character numbers are given in brackets, as follows: length of femur (5), length of tibia (6), metatarsus length (7), tergite 3 , longitudinal (9), tergite 4, longitudinal (10), sternite 3 , longitudinal (11), wax plate of sternite 3 , longitudinal (12), sternite 6 , longitudinal (15), forewing length (17), wing angle B4 (22), wing angle D7 (23) and wing angle G18 (25). The Akahira and Sakagami $(1959 \mathrm{a}, \mathrm{b})$ database had only 2 characters in common with the other databases ((6), (7)), the Szabo (1990) database had only 6 characters ((5), (6), (7), (11), (12), (17)) and 58 colonies from the Grahamstown and Hadisoesilo databases had 6 common characters ((6), (7), (10), (17), B4, D7).

To obviate subjective variation in measurements among different authors, the database of Oberursel was used as a common standard. Then (1) the data for Kampar, Bankkinang and Sukabumi, Indonesia from Sulistianto (1990) and the present study were also corrected against the Obeursel base for the same localities; (2) data for Tenom, North Borneo of this study were matched against Oberursel while (3) data for Anuradhapura and Kandy in Sri Lanka from Oberursel were used to standardize that for Makandura because the apiary contained colonies collected from scattered localities in Sri Lanka (Szabo, 1990).

\subsection{Data analysis}

Multivariate statistical analysis of the data included principal components, kernel density, kmeans cluster and linear discriminant analyses, analysis of variance, Wilks' lambda statistic for testing significant differences between the multiple means of the characters entered into the discriminant functions and Levene's F statistic procedure for testing heterogeneity of variances (Johnson and Wichern, 1998; Rao, 1998). 
Table I. Geographical origins, altitude and colony sample sizes (n) of A. cerana used in the morphometric analysis of honeybees of oceanic Asia*.

\begin{tabular}{|c|c|c|c|c|c|c|c|}
\hline Locality and Map Ref. Nos. & Coordinates & $\begin{array}{l}\text { Alt. } \\
\text { (m) }\end{array}$ & $\mathrm{n}$ & Sources & $\begin{array}{c}\mathrm{G} \\
1\end{array}$ & $\begin{array}{l}\mathrm{G} \\
2\end{array}$ & $\begin{array}{l}\mathrm{G} \\
3\end{array}$ \\
\hline \multicolumn{8}{|l|}{ CHINA } \\
\hline \multicolumn{8}{|l|}{ Hainan } \\
\hline 1. Yongxing ${ }^{\mathrm{a}}$ & $19.53 \mathrm{~N} 110.15 \mathrm{E}$ & 106 & 1 & Kunming & 4 & 4 & \\
\hline 2. Dingan ${ }^{a}$ & $19.41 \mathrm{~N} 110.19 \mathrm{E}$ & 29 & 1 & Kunming & 3 & 4 & \\
\hline 3. Wenchang ${ }^{\mathrm{a}}$ & $19.37 \mathrm{~N} 110.45 \mathrm{E}$ & 21 & 1 & Kunming & 2 & 4 & \\
\hline 4. Qiongzhonga & $19.02 \mathrm{~N} 109.50 \mathrm{E}$ & 219 & 1 & Kunming & 4 & 4 & \\
\hline 5. Jianfeng ${ }^{\mathrm{a}}$ & $18.42 \mathrm{~N} 108.48 \mathrm{E}$ & 74 & 2 & Kunming & 4 & 4 & \\
\hline \multicolumn{8}{|l|}{ INDONESIA } \\
\hline \multicolumn{8}{|l|}{ Sumatera } \\
\hline 1. Medan ${ }^{\mathrm{a}}$ & $3.35 \mathrm{~N} 98.40 \mathrm{E}$ & 50 & 1 & Oberursel & 3 & 3 & \\
\hline 2. Purbatongah ${ }^{\mathrm{a}}$ & $2.53 \mathrm{~N} 98.42 \mathrm{E}$ & 1197 & 2 & Hadisoesilo & & & 3 \\
\hline 3. Bengkalis ${ }^{\mathrm{a}}$ & $1.28 \mathrm{~N} 102.07 \mathrm{E}$ & $<50$ & 2 & Hadisoesilo & & & $?$ \\
\hline 4. Pekanbaru ${ }^{\mathrm{a}}$ & $0.32 \mathrm{~N} 101.25 \mathrm{E}$ & 16 & 1 & Oberursel & 4 & 4 & \\
\hline 5. Sentajo Taluk ${ }^{\mathrm{a}}$ & $0.31 \mathrm{~N} 101.34 \mathrm{E}$ & $<100$ & 2 & Oberursel & 4 & 3 & \\
\hline 6. Kampar ${ }^{\mathrm{a}}$ & $0.21 \mathrm{~N} 101.25 \mathrm{E}$ & $<100$ & 3 & Oberursel & 4 & 3 & \\
\hline 7. Bangkinang ${ }^{\mathrm{a}}$ & $0.21 \mathrm{~N} 101.10 \mathrm{E}$ & 59 & 1 & Sulistianto, 1990 & 4 & 3 & \\
\hline 8. Suliki ${ }^{\mathrm{a}}$ & $0.06 \mathrm{~N} 100.27 \mathrm{E}$ & 585 & 2 & Hadisoesilo & & & 3 \\
\hline 9. Padang ${ }^{\mathrm{a}}$ & $0.55 \mathrm{~S} 100.17 \mathrm{E}$ & 98 & 1 & Oberursel & 3 & 4 & \\
\hline \multicolumn{8}{|l|}{ Kalimantan } \\
\hline 1. Barabai ${ }^{\mathbf{a}}$ & $2.34 \mathrm{~S} 115.22 \mathrm{E}$ & 100 & 2 & Hadisoesilo & 3 & 3 & \\
\hline \multicolumn{8}{|l|}{ Sulawesi } \\
\hline 1. Lolu ${ }^{\mathrm{a}}$ & $0.45 \mathrm{~S} 119.46 \mathrm{E}$ & 23 & 3 & Hadisoesilo; this study & & & 4 \\
\hline 2. $\mathrm{Palu}^{\mathrm{a}}$ & $0.54 \mathrm{~S} 119.51 \mathrm{E}$ & 23 & 5 & Hadisoesilo; this study & & & 4 \\
\hline 3. Rahmat ${ }^{\mathrm{a}}$ & $1.25 \mathrm{~S} 120.11 \mathrm{E}$ & 630 & 6 & Hadisoesilo; this study & & & 4 \\
\hline 4. Kamarora ${ }^{a}$ & $1.25 \mathrm{~S} 120.11 \mathrm{E}$ & 630 & 6 & $\begin{array}{l}\text { Damus \& Otis, 1997; } \\
\text { Hadisoesilo; this study }\end{array}$ & & & 4 \\
\hline 5. Tappalang ${ }^{\mathrm{a}}$ & $2.51 \mathrm{~S} 118.53 \mathrm{E}$ & 50 & 1 & Hadisoesilo & & & 3 \\
\hline 6. Kambuno ${ }^{\mathrm{a}}$ & $3.14 \mathrm{~S} 120.05 \mathrm{E}$ & 893 & 1 & Hadisoesilo & & & 3 \\
\hline 7. Sinjai ${ }^{\mathbf{a}}$ & $5.07 \mathrm{~S} 120.15 \mathrm{E}$ & $\sim 300$ & 2 & Hadisoesilo & & & 3 \\
\hline 8. Bantaeng ${ }^{\mathbf{a}}$ & $5.32 \mathrm{~S} 119.57 \mathrm{E}$ & 23 & 8 & Hadisoesilo & 4 & 4 & 3 \\
\hline 9. Bulukumba ${ }^{\mathrm{a}}$ & $5.35 \mathrm{~S} 120.13 \mathrm{E}$ & 1 & 18 & Hadisoesilo; this study & & & 3 \\
\hline 10. Jeneponto ${ }^{\mathrm{a}}$ & $5.42 \mathrm{~S} 119.44 \mathrm{E}$ & 10 & 3 & $\begin{array}{l}\text { Damus \& Otis, 1997; } \\
\text { Hadisoesilo; this study }\end{array}$ & 4 & 4 & 3 \\
\hline \multicolumn{8}{|l|}{ Java } \\
\hline 1. Jakarta ${ }^{\mathrm{a}}$ & $6.10 \mathrm{~S} 106.47 \mathrm{E}$ & 1 & 2 & Oberursel & 4 & 4 & \\
\hline 2. Parungpanjang ${ }^{\mathrm{a}}$ & 6.20S 106.32E & 91 & 8 & $\begin{array}{l}\text { Damus \& Otis, 1997; Oberursel; } \\
\text { this study }\end{array}$ & 4 & 4 & \\
\hline 3. Tjandjoer $(=\text { Cianjur })^{\mathrm{a}}$ & $6.50 \mathrm{~S} 107.09 \mathrm{E}$ & 472 & 3 & Damus \& Otis, 1997; this study & 4 & 4 & \\
\hline
\end{tabular}


Table I. Continued.

\begin{tabular}{|c|c|c|c|c|c|c|c|}
\hline Locality and Map Ref. Nos. & Coordinates & $\begin{array}{l}\text { Alt. } \\
\text { (m) }\end{array}$ & $\mathrm{n}$ & Sources & $\begin{array}{c}\mathrm{G} \\
1\end{array}$ & $\begin{array}{l}\mathrm{G} \\
2\end{array}$ & $\begin{array}{l}\mathrm{G} \\
3\end{array}$ \\
\hline 4. Sukabumi ${ }^{\mathrm{a}}$ & $6.55 \mathrm{~S} 106.55 \mathrm{E}$ & 21 & 8 & Sulistianto, 1990; Oberursel & 4 & 4 & \\
\hline 5. Kebasen ${ }^{\mathrm{a}}$ & $7.31 \mathrm{~S} 109.10 \mathrm{E}$ & 58 & 1 & Hadisoesilo & 4 & 4 & \\
\hline 6. Klaten ${ }^{\mathrm{a}}$ & $7.42 \mathrm{~S} 110.34 \mathrm{E}$ & 193 & 3 & Hadisoesilo & 4 & 4 & \\
\hline 7. Tretes ${ }^{\mathrm{a}}$ & 7.51S 112.34E & 900 & 4 & $\begin{array}{l}\text { Sulistianto, 1990; Damus \& } \\
\text { Otis, 1997; Hadisoesilo; this } \\
\text { study }\end{array}$ & 4 & 4 & \\
\hline 8. Bantul ${ }^{\mathrm{a}}$ & $7.54 \mathrm{~S} 110.19 \mathrm{E}$ & 36 & 1 & Sulistianto, 1990 & 4 & 4 & \\
\hline \multicolumn{8}{|l|}{ Bali } \\
\hline 1. Karangasem ${ }^{\mathrm{a}}$ & $8.26 \mathrm{~S} 115.37 \mathrm{E}$ & 0 & 1 & Sulistianto, 1990 & 4 & 4 & \\
\hline 2. Tunjungan ${ }^{\mathrm{a}}$ & $8.37 \mathrm{~S} 115.05 \mathrm{E}$ & 152 & 5 & Damus \& Otis, 1997; this study & 4 & 4 & \\
\hline \multicolumn{8}{|l|}{ Lombok } \\
\hline 1. Senggigi/Gunungsaric ${ }^{\mathrm{c}}$ & $\sim 8.30 \mathrm{~S} 116.30 \mathrm{E}$ & 334 & - & Damus \& Otis, 1997 & & & \\
\hline 2. Lombok ${ }^{\mathrm{a}}$ & $8.30 \mathrm{~S} 116.40 \mathrm{E}$ & 6 & 1 & Oberursel & 3 & 3 & \\
\hline \multicolumn{8}{|l|}{ Sumbawa } \\
\hline 1. Sumbawa ${ }^{a}$ & 8.29S $117.25 \mathrm{E}$ & 79 & 1 & Oberursel & 2 & 2 & \\
\hline \multicolumn{8}{|l|}{ Flores } \\
\hline 1. Labuhanbadjo ${ }^{\mathrm{a}}$ & $8.31 \mathrm{~S} 119.53 \mathrm{E}$ & 153 & 2 & Oberursel & 2 & 2 & \\
\hline 2. Ende ${ }^{c}$ & $8.51 \mathrm{~S} 121.40 \mathrm{E}$ & 0 & - & Damus \& Otis, 1997 & & & \\
\hline \multicolumn{8}{|l|}{ Timor } \\
\hline 1. Loli ${ }^{\mathrm{a}}$ & $9.40 \mathrm{~S} 124.31 \mathrm{E}$ & 322 & 1 & Oberursel & 3 & 3 & \\
\hline 2. Kupang ${ }^{\mathrm{c}}$ & $10.13 \mathrm{~S} 123.38 \mathrm{E}$ & 74 & - & Damus \& Otis, 1997 & & & \\
\hline \multicolumn{8}{|l|}{ Ambon } \\
\hline 1. Ambon ${ }^{\mathrm{a}}$ & $3.35 \mathrm{~S} 128.09 \mathrm{E}$ & 297 & 1 & Oberursel & 3 & 3 & \\
\hline \multicolumn{8}{|l|}{ Irian Jaya } \\
\hline 1. Koya Timur ${ }^{\mathrm{a}}$ & $2.32 \mathrm{~S} 140.42 \mathrm{E}$ & $?$ & 3 & Oberursel & 4 & 4 & \\
\hline \multicolumn{8}{|l|}{ JAPAN } \\
\hline 1. Tokyo ${ }^{\mathrm{a}}$ & $35.41 \mathrm{~N} 139.46 \mathrm{E}$ & 14 & 2 & Damus \& Otis, 1997; Oberursel & 1 & 1 & \\
\hline 2. Fukuoka ${ }^{a}$ & $35.34 \mathrm{~N} 137.26 \mathrm{E}$ & 330 & 1 & Oberursel & 1 & 1 & \\
\hline 3. Yamanashi ${ }^{\mathrm{a}}$ & $34.47 \mathrm{~N} 137.54 \mathrm{E}$ & 34 & 1 & Oberursel & 1 & 1 & \\
\hline 4. Izuhara ${ }^{\mathrm{a}}$ & $34.14 \mathrm{~N} 129.15 \mathrm{E}$ & 23 & 4 & Oberursel & 1 & 1 & \\
\hline 5. Yamaguchi ${ }^{b}$ & $34.16 \mathrm{~N} 135.16 \mathrm{E}$ & 53 & 3 & Akahira \& Sakagami, 1959a & & & 1 \\
\hline 6. Oishi ${ }^{b}$ & $33.25 \mathrm{~N} 130.35 \mathrm{E}$ & 60 & 1 & Akahira \& Sakagami, 1959b & & & 1 \\
\hline 7. Nishijima ${ }^{\mathrm{b}}$ & $33.25 \mathrm{~N} 130.35 \mathrm{E}$ & 25 & 1 & Akahira \& Sakagami, 1959b & & & 1 \\
\hline 8. Sakashita ${ }^{b}$ & $32.45 \mathrm{~N} 129.52 \mathrm{E}$ & 35 & 1 & Akahira \& Sakagami, 1959b & & & 1 \\
\hline 9. Noze ${ }^{b}$ & $32.13 \mathrm{~N} 131.08 \mathrm{E}$ & 460 & 1 & Akahira \& Sakagami, 1959b & & & 1 \\
\hline 10. Koshinoo ${ }^{\mathrm{b}}$ & $32.12 \mathrm{~N} 131.15 \mathrm{E}$ & 330 & 1 & Akahira \& Sakagami, 1959b & & & 1 \\
\hline 11. Kaname ${ }^{\mathrm{b}}$ & $32.11 \mathrm{~N} 130.42 \mathrm{E}$ & 520 & 1 & Akahira \& Sakagami, 1959b & & & 1 \\
\hline
\end{tabular}


Table I. Continued.

\begin{tabular}{lccccccc}
\hline Locality and Map Ref. Nos. & Coordinates & $\begin{array}{c}\text { Alt. } \\
(\mathrm{m})\end{array}$ & $\mathrm{n}$ & Sources & $\begin{array}{c}\mathrm{G} \\
1\end{array}$ & $\begin{array}{c}\mathrm{G} \\
2\end{array}$ & $\begin{array}{c}\mathrm{G} \\
3\end{array}$ \\
\hline 12. Yumino $^{\mathrm{b}}$ & $32.01 \mathrm{~N} 130.12 \mathrm{E}$ & 30 & 1 & Akahira \& Sakagami, 1959b & & 1 \\
13. Iwangochi $^{\mathrm{b}}$ & $30.17 \mathrm{~N} 130.59 \mathrm{E}$ & 320 & 1 & Akahira \& Sakagami, 1959b & & 1
\end{tabular}

NORTH BORNEO (Malaysia)

1. Kota Belud
2. Mt Kinabalu
3. Tambunan
a
4. Apin Apin
5. Tenoma
6. Tawau
7. Kuching

PAPUA NEW GUINEA
6

$6.04 \mathrm{~N} 116.27 \mathrm{E} \quad 3943 \quad 3$ Oberursel

$5.40 \mathrm{~N} 116.21 \mathrm{E} \quad 792 \quad 7$ Oberursel

$5.28 \mathrm{~N} 116.16 \mathrm{E} \quad 452 \quad 1$ Oberursel

$5.07 \mathrm{~N} 115.56 \mathrm{E}$

$4.14 \mathrm{~N} 117.52 \mathrm{E}$

$1.33 \mathrm{~N} 110.19 \mathrm{E}$

231

$7 \quad$ Rir

$98 \quad 13$ Oberursel

72 This study Otis, 1997; t., 1989, Damus \&

2.55S 141.17E $152 \quad 2$ Oberursel; this study

5.07S 141.38E 12402 Oberursel; this study

5.13S 142.13E $\quad \sim 15002$ Oberursel; this study

6.04S 145.22E $1524 \quad 4$ Oberursel; this study

7.13S $146.00 \mathrm{E}$

8.33S $147.15 \mathrm{E}$

14521 Oberursel
2.41S $141.18 \mathrm{E} \quad 14$ Oberursel; this study

33

33

33

33

33

3

3

7. Fatima-Benz ${ }^{\mathrm{a}}$

PHILIPPINES

\section{Luzon}

1. Batac ${ }^{\mathrm{a}}$

2. San Vincente ${ }^{a}$

3. $\mathrm{Caba}^{\mathrm{a}}$

4. San Fernando ${ }^{a}$

5. Tublay ${ }^{\mathrm{a}}$

6. Baguio City ${ }^{\mathrm{a}}$

7. San Jose City ${ }^{\mathrm{a}}$

8. Quezon City ${ }^{\mathrm{c}}$

9. Santa Cruza

10. Los Banos ${ }^{\mathrm{a}}$

11. Laguna City ${ }^{\mathrm{a}}$

12. Rizal \& Nagcarlan ${ }^{\mathrm{a}}$

13. Alfonso ${ }^{\mathrm{a}}$

14. Tanauan ${ }^{\mathrm{a}}$

15. Batangas ${ }^{\mathrm{a}}$

$\begin{array}{lcclll}18.03 \mathrm{~N} 120.33 \mathrm{E} & 41 & 5 & \text { Tilde et al., 2000 } & 3 & 3 \\ 17.45 \mathrm{~N} 120.25 \mathrm{E} & 5 & 1 & \text { Tilde et al., 2000 } & 3 & 3 \\ 16.47 \mathrm{~N} 121.08 \mathrm{E} & 770 & 1 & \text { Oberursel } & 2 & 2 \\ 16.36 \mathrm{~N} 120.18 \mathrm{E} & 55 & 2 & \text { Oberursel } & 3 & 3 \\ 16.26 \mathrm{~N} 120.34 \mathrm{E} & 1000 & 1 & \text { Tilde et al., 2000 } & 3 & 3 \\ 16.24 \mathrm{~N} 120.35 \mathrm{E} & 1450 & 7 & \text { Tilde et al., 2000, Oberursel } & ? & 2 \\ 15.46 \mathrm{~N} 120.58 \mathrm{E} & 2 & 1 & \text { Tilde et al., 2000 } & 3 & 3 \\ 14.39 \mathrm{~N} 121.01 \mathrm{E} & 34 & - & \text { Damus \& Otis, 1997 } & & \\ 14.16 \mathrm{~N} 121.24 \mathrm{E} & 18 & 1 & \text { Damus \& Otis, 1997; this study } & & \\ 14.10 \mathrm{~N} 121.21 \mathrm{E} & 41 & 1 & \text { Tilde et al., 2000 } & 2 & 2 \\ 14.10 \mathrm{~N} 121.17 \mathrm{E} & 5 & 2 & \text { Damus \& Otis, 1997; } & 2 & 2 \\ 14.08 \mathrm{~N} 121.24 \mathrm{E} & 252 & 4 & \text { Tilde et al., 2000 } & & \\ 14.08 \mathrm{~N} 120.50 \mathrm{E} & 431 & 1 & \text { Oberursel } & 3 & 3 \\ 14.05 \mathrm{~N} 121.08 \mathrm{E} & 159 & 1 & \text { Oberursel } & 2 & 2 \\ 13.45 \mathrm{~N} 121.03 \mathrm{E} & 51 & 1 & \text { Oberursel } & 2 & 2 \\ & & & & 3 & 3\end{array}$


Table I. Continued.

\begin{tabular}{|c|c|c|c|c|c|c|c|}
\hline Locality and Map Ref. Nos. & Coordinates & $\begin{array}{l}\text { Alt. } \\
\text { (m) }\end{array}$ & $\mathrm{n}$ & Sources & $\begin{array}{c}\mathrm{G} \\
1\end{array}$ & $\begin{array}{l}\mathrm{G} \\
2\end{array}$ & $\begin{array}{l}\mathrm{G} \\
3\end{array}$ \\
\hline 16. Sorsogon ${ }^{a}$ & $12.58 \mathrm{~N} 124.00 \mathrm{E}$ & 4 & 1 & Oberursel & 3 & 3 & \\
\hline \multicolumn{8}{|l|}{ Mindoro } \\
\hline 1. Min Oriental ${ }^{\mathrm{a}}$ & $13.24 \mathrm{~N} 121.10 \mathrm{E}$ & $\sim 750$ & 1 & Oberursel & 2 & 2 & \\
\hline \multicolumn{8}{|l|}{ Palawan } \\
\hline 1. El Nido ${ }^{\mathrm{a}}$ & $11.11 \mathrm{~N} 119.22 \mathrm{E}$ & 95 & 4 & Tilde et al., 2000 & 3 & 3 & \\
\hline 2. Taytay ${ }^{\mathrm{a}}$ & $10.48 \mathrm{~N} 119.26 \mathrm{E}$ & 159 & 3 & Tilde et al., 2000 & 3 & 3 & \\
\hline 3. Roxas ${ }^{\mathrm{a}}$ & $10.19 \mathrm{~N} 119.20 \mathrm{E}$ & 11 & 6 & Tilde et al., 2000 & $?$ & 3 & \\
\hline 4. Puerta Princesa ${ }^{a}$ & $9.44 \mathrm{~N} 118.43 \mathrm{E}$ & 0 & 11 & Tilde et al., 2000 & 3 & 3 & \\
\hline 5. Aborlan ${ }^{\mathrm{a}}$ & $9.26 \mathrm{~N} 118.31 \mathrm{E}$ & 3 & 9 & Tilde et al., 2000; Oberursel & 3 & 3 & \\
\hline 6. Quezon ${ }^{\mathrm{a}}$ & $9.15 \mathrm{~N} 117.58 \mathrm{E}$ & 0 & 8 & Tilde et al., 2000 & 3 & 3 & \\
\hline 7. Brooke's Point ${ }^{\mathrm{a}}$ & $8.46 \mathrm{~N} 117.50 \mathrm{E}$ & 9 & 7 & Tilde et al., 2000 & 3 & 3 & \\
\hline \multicolumn{8}{|l|}{ Visayas } \\
\hline 1. Valencia ${ }^{\mathrm{a}}$ & $10.39 \mathrm{~N} 122.42 \mathrm{E}$ & 4 & 5 & Tilde et al., 2000, Oberursel & 2 & 2 & \\
\hline 2. San Joaquin ${ }^{\mathrm{a}}$ & $10.35 \mathrm{~N} 122.08 \mathrm{E}$ & 0 & 5 & Tilde et al., 2000 & $?$ & 2 & \\
\hline 3. Hinunangan ${ }^{\mathrm{a}}$ & $10 \cdot 23 \mathrm{~N} 125.11 \mathrm{E}$ & 1 & 3 & Oberursel & 2 & 2 & \\
\hline 4. Cebu ${ }^{\mathrm{a}}$ & $10.19 \mathrm{~N} 123.53 \mathrm{E}$ & 3 & 1 & Oberursel & 2 & 2 & \\
\hline 5. Isabela ${ }^{\mathrm{a}}$ & $10.12 \mathrm{~N} 122.59 \mathrm{E}$ & 64 & 2 & Tilde et al., 2000 & 2 & 2 & \\
\hline 6. $\operatorname{Argao}^{\mathrm{a}}$ & $9.52 \mathrm{~N} 123.36 \mathrm{E}$ & 0 & 2 & Tilde et al., 2000, Oberursel & 3 & 2 & \\
\hline 7. Negros Occidentala & $9.19 \mathrm{~N} 123.03 \mathrm{E}$ & $\sim 500$ & 1 & Tilde et al., 2000 & 2 & 2 & \\
\hline \multicolumn{8}{|l|}{ Mindanao } \\
\hline 1. Carmen City ${ }^{\mathrm{a}}$ & $8.58 \mathrm{~N} 126.15 \mathrm{E}$ & 36 & 1 & Tilde et al., 2000 & 2 & 2 & \\
\hline 2. Cagayan de Oroa & $8.29 \mathrm{~N} 124.38 \mathrm{E}$ & 34 & 3 & Oberursel & 2 & 2 & \\
\hline 3. Kauswagan ${ }^{\mathrm{a}}$ & $8.11 \mathrm{~N} 124.05 \mathrm{E}$ & 72 & 1 & Damus \& Otis, 1997; Oberursel & 2 & 2 & \\
\hline 4. Bunawan ${ }^{\mathrm{a}}$ & $8.10 \mathrm{~N} 125.59 \mathrm{E}$ & 19 & 1 & Tilde et al., 2000 & 2 & 2 & \\
\hline 5. Ozamis ${ }^{\mathrm{a}}$ & $8.09 \mathrm{~N} 123.50 \mathrm{E}$ & 1 & 1 & Tilde et al., 2000 & 2 & 2 & \\
\hline 6. Asuncion ${ }^{\mathrm{a}}$ & $7.32 \mathrm{~N} 125.44 \mathrm{E}$ & 13 & 2 & Oberursel & 3 & 2 & \\
\hline 7. $P a n a b o^{a}$ & $7.22 \mathrm{~N} 125.44 \mathrm{E}$ & 4 & 4 & Tilde et al., 2000; this study & 3 & 3 & 3 \\
\hline 8. Samalia ${ }^{a}$ & $7.04 \mathrm{~N} 125.42 \mathrm{E}$ & 7 & 1 & This study & & & 2 \\
\hline 9. Kidapawan ${ }^{a}$ & $7.00 \mathrm{~N} 125.05 \mathrm{E}$ & 251 & 3 & Tilde et al., 2000 & 2 & 2 & \\
\hline 10. Davao ${ }^{\mathrm{a}}$ & $6.56 \mathrm{~N} 125.46 \mathrm{E}$ & 0 & 4 & Tilde et al., 2000; this study & 3 & 2 & 2 \\
\hline 11. Digos ${ }^{\mathrm{a}}$ & $6.45 \mathrm{~N} 125.21 \mathrm{E}$ & 0 & 3 & Tilde et al., 2000 & $?$ & 2 & \\
\hline 12. Bacnotan $^{\mathrm{a}}$ & $6.42 \mathrm{~N} 126.05 \mathrm{E}$ & $\sim 1200$ & 1 & Tilde et al., 2000 & 3 & 3 & \\
\hline 13. Takurong ${ }^{\mathrm{a}}$ & $6.40 \mathrm{~N} 124.40 \mathrm{E}$ & 39 & 1 & Tilde et al., 2000 & 3 & 3 & \\
\hline 14. Malita ${ }^{a}$ & $6.24 \mathrm{~N} 125.36 \mathrm{E}$ & 0 & 2 & Tilde et al., 2000 & $?$ & 2 & \\
\hline 15. Hagonoy ${ }^{\mathrm{a}}$ & $6.19 \mathrm{~N} 125.37 \mathrm{E}$ & 17 & 1 & Tilde et al., 2000 & 3 & 3 & \\
\hline 16. Polomolok ${ }^{\mathrm{a}}$ & $6.13 \mathrm{~N} 125.03 \mathrm{E}$ & 264 & 1 & Tilde et al., 2000 & $?$ & 2 & \\
\hline 17. General Santos Citya & $6.01 \mathrm{~N} 125.16 \mathrm{E}$ & 16 & 1 & Tilde et al., 2000 & 2 & 2 & \\
\hline
\end{tabular}


Table I. Continued.

\begin{tabular}{|c|c|c|c|c|c|c|c|}
\hline Locality and Map Ref. Nos. & Coordinates & $\begin{array}{l}\text { Alt. } \\
\text { (m) }\end{array}$ & $\mathrm{n}$ & Sources & $\begin{array}{c}\mathrm{G} \\
1\end{array}$ & $\begin{array}{c}\mathrm{G} \\
2\end{array}$ & $\begin{array}{l}\mathrm{G} \\
3\end{array}$ \\
\hline \multicolumn{8}{|l|}{ SRI LANKA } \\
\hline 1. Anuradhapura ${ }^{a}$ & $8.18 \mathrm{~N} 80.24 \mathrm{E}$ & 82 & 4 & Oberursel & 4 & 4 & \\
\hline 2. Makandura ${ }^{a}$ & $7.19 \mathrm{~N} 79.58 \mathrm{E}$ & 18 & 11 & Szabo, 1990 & & & 4 \\
\hline 3. Kandy ${ }^{\mathrm{a}}$ & $7.16 \mathrm{~N} 80.37 \mathrm{E}$ & 473 & 1 & Oberursel & 4 & 4 & \\
\hline 4. Horana ${ }^{a}$ & $6.43 \mathrm{~N} 80.04 \mathrm{E}$ & 90 & 5 & Damus \& Otis, 1997; this study & 4 & 4 & \\
\hline
\end{tabular}

* Those for which the original raw data are available are indicated by "a", those for which the original raw data are not available but were in a form that allowed their inclusion are indicated by "b", those for which the final conclusions of the authors could be used, by "c".

G1 and G2 indicate the morphoclusters in which the colonies were classified with the cluster analysis and discriminant analysis procedures, respectively. G3 indicates the clusters in which the colonies from databases with processed data or fewer than 12 characters were classified. ?: indicates the localities where the colonies are unclassified.

\section{RESULTS}

\subsection{Mesoscale analysis on combined oceanic databases}

Principal components analysis was carried out on the total morphometric oceanic databases of Oberursel, Kunming, Hadisoesilo, Grahamstown, Akahira and Sakagami (1959a, b), Rinderer et al. (1989), Sulistianto (1990), Szabo (1990) and Tilde et al. (2000) comprising 346 colonies. Using twelve morphometric characters of worker honeybees $((5),(6),(7)$, (9), (10), (11), (12), (15), (17), B4, D7, G18) shared among the databases reduced the number of colonies in the analysis to 260 . Two principal components with eigenvalues greater than one were isolated: PC 1, size-related characters (5), (6), (7), (9), (10), (11), (12), (15) and (17) with component loadings between 0.80 and 0.92 accounting for $58.7 \%$ of the variation; PC 2, angles of venation B4 and G18 with component loadings 0.68 and 0.71 , respectively, accounted for $11.0 \%$ of the variation. The two principal components accounted for a total of $69.7 \%$ of the variation in the data.

PC plots using both the first and second PC scores, and the first and third PC scores revealed two distinct morphoclusters: a group of larger bees from Japan and a second group comprising bees from Indonesia, North Borneo (Malaysia), Papua New Guinea, Philippines, Sri Lanka and Hainan (China).
Kernel density plots revealed the same two morphoclusters. Further substructuring of the second morphocluster could not initially be derived from the PC plots; because only by first introducing local labelling does it become clear that bees from different localities form overlapping regional clusters: (a) Philippines (Luzon, Mindoro, Visayas, Mindanao) in the upper half of the morphocluster; (b) Philippines (Palawan), Malaysia (North Borneo), Indonesia (Kalimantan and some colonies from Sumatera) and Hainan in the centre of the morphocluster; and, (c) Indonesia (Java, Bali, Irian Jaya, Sulawesi, some Sumatera), Papua New Guinea and Sri Lanka in the lower half of the morphocluster (Fig. 2).

In order to statistically determine the number of regional clusters within the second morphocluster, discriminant analysis with islands as the grouping factor was used to compute the island mean canonical scores. The following Indonesian islands were not included in the analysis due to insufficient data: Lombok, Sumbawa, Flores, Timor and Ambon. Results of an hierarchical cluster analysis (Quinn and Keough, 2002) on the island mean canonical scores yielded a dendrogram of four main clusters (Fig. 3). Phenetically, regional cluster 2.1 first linked the colonies from Visayas and Mindanao, then Luzon; regional cluster 2.2 first linked colonies from Sumatera and Kalimantan (Indonesia) and Sabah and Sarawak (Malaysia), followed by those from Palawan; 

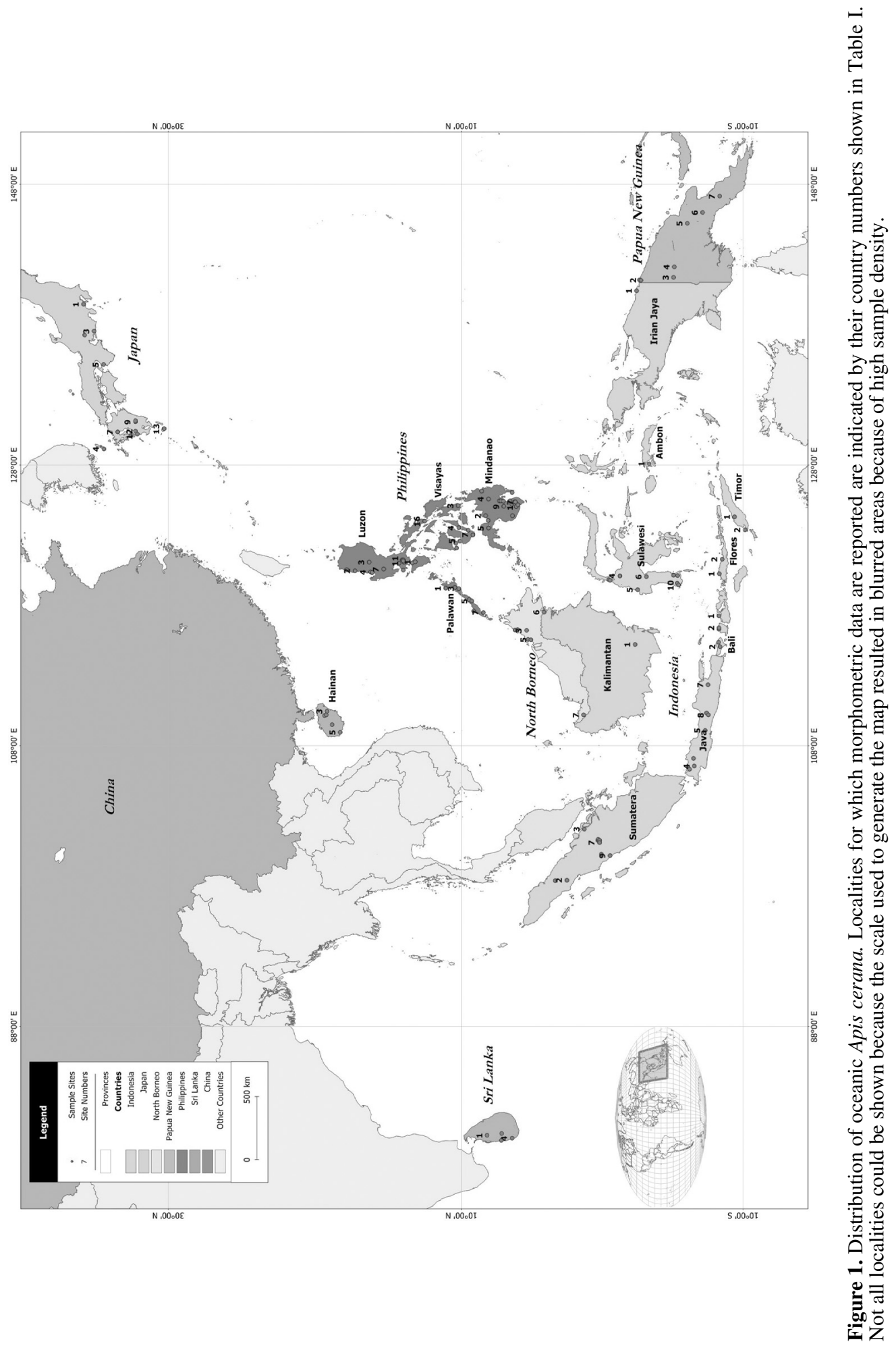


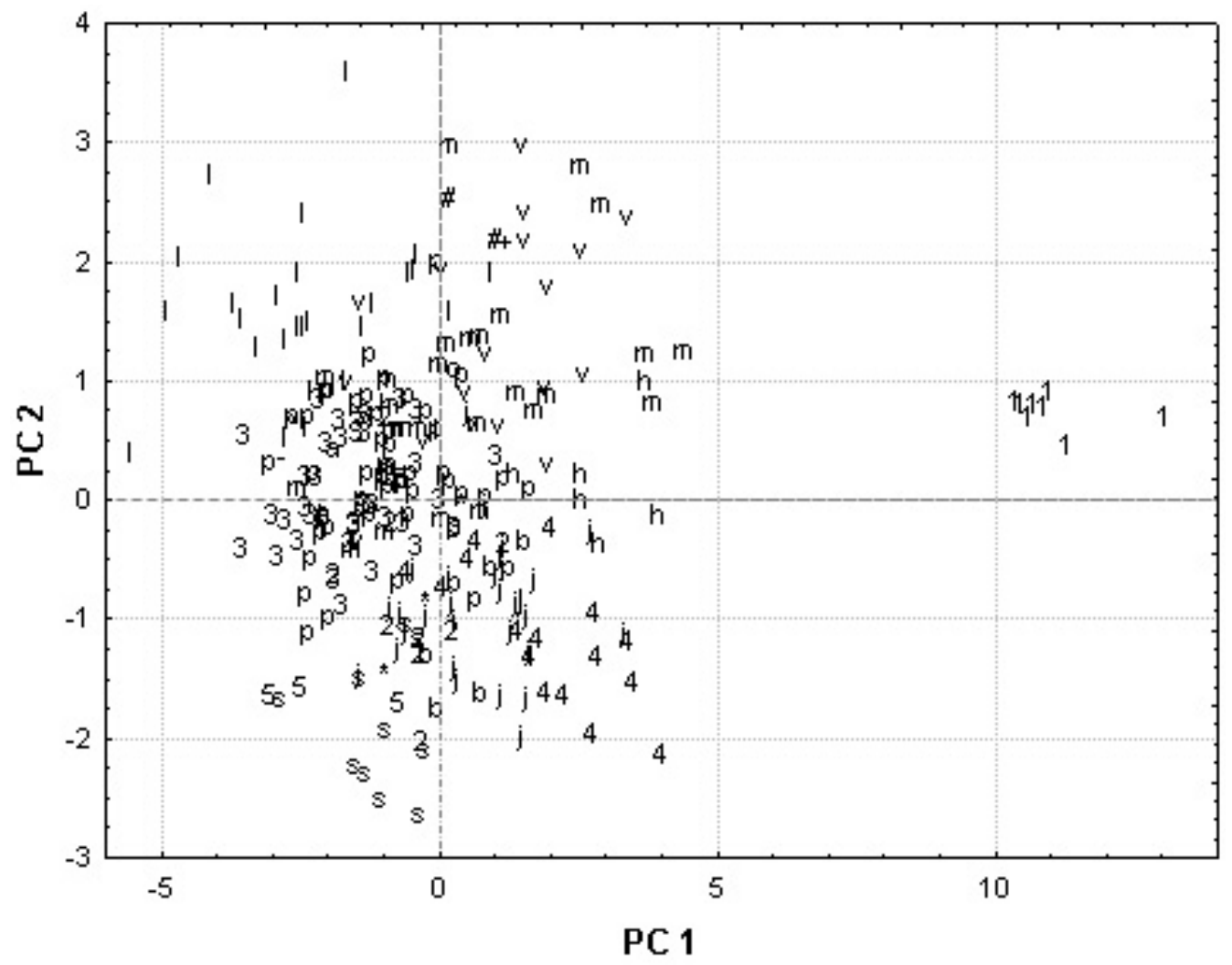

Figure 2. Factor scores $(\mathrm{PC})$ of colony samples of $A$. cerana $(\mathrm{n}=260$ colonies $)$ from $1=$ Japan, $2=$ Sumatera, $3=$ Borneo, $4=$ Papua New Guinea, $5=$ Sulawesi, $\mathrm{a}=$ Ambon, $\mathrm{b}=$ Bali, $\mathrm{h}=$ Hainan, $\mathrm{j}=\mathrm{Java}$, $\mathrm{l}=$ Luzon, $\mathrm{m}=$ Mindanao, $\mathrm{o}=$ Mindoro, $\mathrm{p}=$ Palawan, $\mathrm{s}=$ Sri Lanka, $\mathrm{v}=$ Visayas, $\#=$ Flores,$+=$ Sumbawa, $*=$ Irian Jaya, $-=$ Timor, ${ }^{\wedge}=$ Lombok.

regional cluster 2.3 linked colonies from Java, Irian Jaya, Bali followed by those from Papua New Guinea and Hainan, and finally Sulawesi and Sri Lanka; lastly colonies from Japan were linked with clusters 2.1,2.2 and 2.3. Mahalanobis squared distances between the centroids of the island bees confirmed these four groups (Tab. IIa).

Having established four regional clusters, a $\mathrm{k}$-means cluster analysis was used to group the colonies (Tab. I, column G1). Lastly, discriminant analysis procedures were used to obtain the final groupings of the colonies by maximizing the percentages of correct classification of the colonies in the four regional clusters (Tab. I, column G2). Colonies from Japan (Nos. 1-4) formed one cluster (1); those from Philippines: Luzon (Nos. 3, 6, 10, 11, 13, 14),
Mindanao (Nos. 1-6, 9-11, 14, 16, 17), Mindoro (No. 1), Visayas (Nos. 1-7) and Indonesia: Flores (No. 1), Sumbawa (No. 1) another cluster (2); those from Malaysia: North Borneo (Nos. 1-7), Philippines: Palawan (Nos. 1-7), Luzon (Nos. 1, 2, 4, 5, 7, 12, 15, 16), Mindanao (Nos. 7, 12, 13, 15) and Indonesia: Kalimantan (No. 1), Ambon (No. 1), Lombok (No. 2), Sumatera (Nos. 1, 5-7), Timor (No. 1) a third cluster (3); Papua New Guinea (Nos. 1-7), Indonesia: Irian Jaya (No. 1), Java (Nos. 1-8), Bali (Nos. 1-2), Sumatera (Nos. 4, 9), Sulawesi (Nos. 8, 10), Hainan (Nos. 1-5) and Sri Lanka (Nos. 1, 3, 4) formed a fourth cluster (4) (Fig. 2, Tab. I).

The discriminant analysis results classified $100 \%$ of colonies $(n=8)$ from Japan correctly into cluster 1 (larger bees); $96.5 \%$ of the colonies 


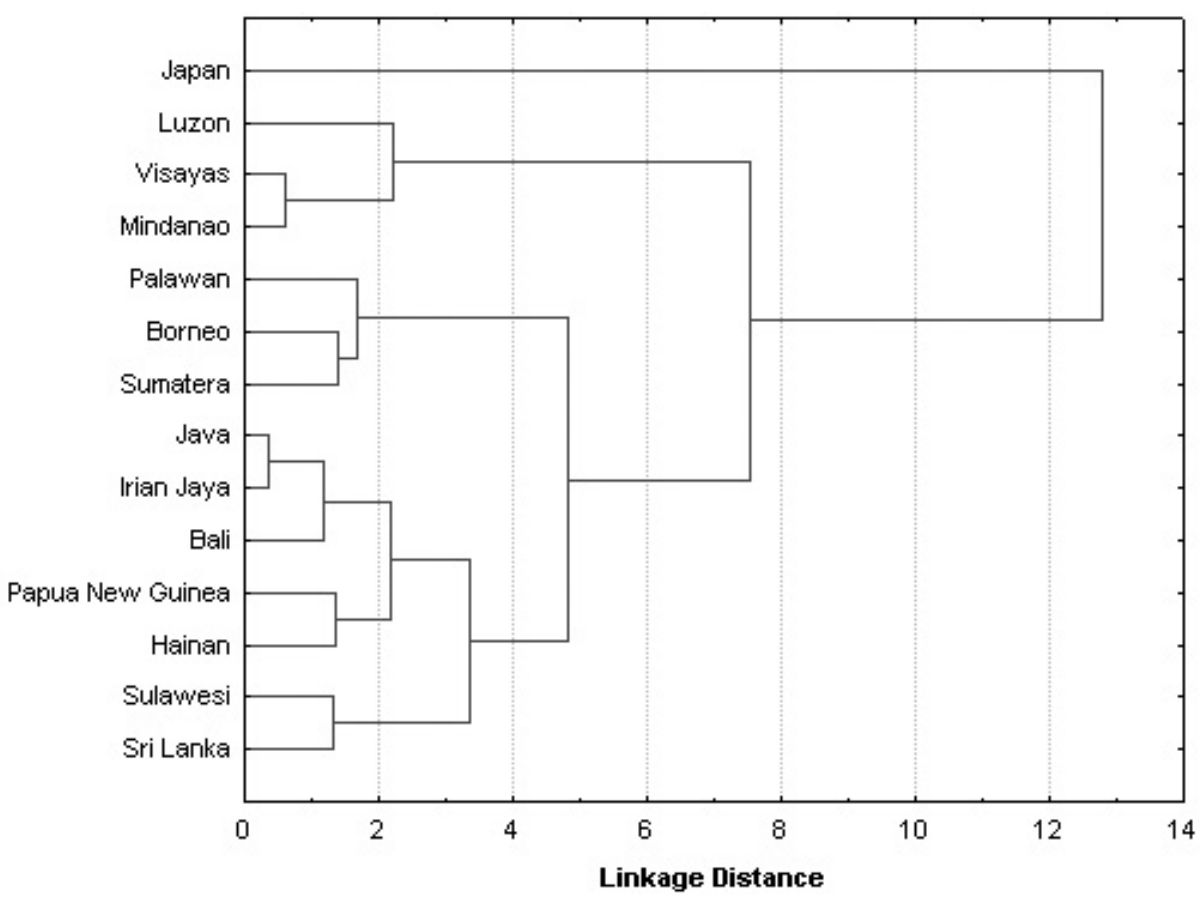

Figure 3. Hierarchical clustering dendrogram for oceanic A. cerana, derived from single linkage clustering on morphometric characters (length of femur (5); length of tibia (6); metatarsus length (7); tergite 3; longitudinal (9); tergite 4; longitudinal (10); sternite 3, longitudinal (11); wax plate of sternite 3, longitudinal (12); sternite 6, longitudinal (15); forewing length (17); wing angle B4 (22); wing angle D7 (23); wing angle G18 (25)) averaged for islands.

$(\mathrm{n}=57)$ from Philippines: Luzon, Mindanao, Mindoro, Visayas and Indonesia: Flores, Sumbawa into cluster 2 but misclassified two colonies into cluster $3 ; 91.6 \%$ of the colonies $(\mathrm{n}=119)$ from Malaysia: North Borneo, Philippines: Palawan, Luzon, Mindanao, Visayas and Indonesia: Kalimantan, Ambon, Lombok, some Sumatera, Timor into cluster 3 and misclassified six colonies into cluster 2 and four colonies into cluster 4 and $96.1 \%$ of the colonies $(\mathrm{n}=76)$ from Papua New Guinea, Hainan (China), Indonesia: Irian Jaya, Java, Bali, Sulawesi, some Sumatera and Sri Lanka into cluster 4 and misclassified three colonies into cluster 3 . To test the equality of the group means for the characters used in the discriminant function, Wilks' lambda approximated by the F statistic was determined. A significant difference between the means of the four groups was established $\left(\Lambda=0.028, \mathrm{~F}_{36,724}=\right.$ 47.2, $P<0.0001)$. The squared Mahalanobis distances between the centroids of the clusters were, in ascending order, $\mathrm{d}^{2}=10.7$ between clusters 2 and $3 ; \mathrm{d}^{2}=12.8$ between clusters 3 and $4 ; \mathrm{d}^{2}=26.6$ between clusters 2 and $4 ; \mathrm{d}^{2}=114.7$ between clusters 1 and $4 ; \mathrm{d}^{2}=119.9$ between clusters 1 and 2 and $\mathrm{d}^{2}=151.1$ between clusters 1 and 3 . The colony means and standard deviations of 12 morphometric characters $((5),(6)$, (7), (9), (10), (11), (12), (15), (17), B4, D7, G18) averaged for morphoclusters are shown in Table III.

Using 12 characters in the analysis excluded Japan data (11 colonies, Akahira and Sakagami, 1959a, b), Sri Lanka data (11 colonies, Szabo, 1990) and 64 colonies from the Grahamstown and Hadisoesilo databases. The analysis was, therefore, repeated using 6 characters $((6),(7)$, (10), (17), B4, D7). This included the total Grahamstown and Hadisoesilo databases and increased the number of colonies in the analysis to 324 and gave very similar results with four clusters. Colonies from Tenom (No. 5; N. Borneo) were again classified in cluster 3; 


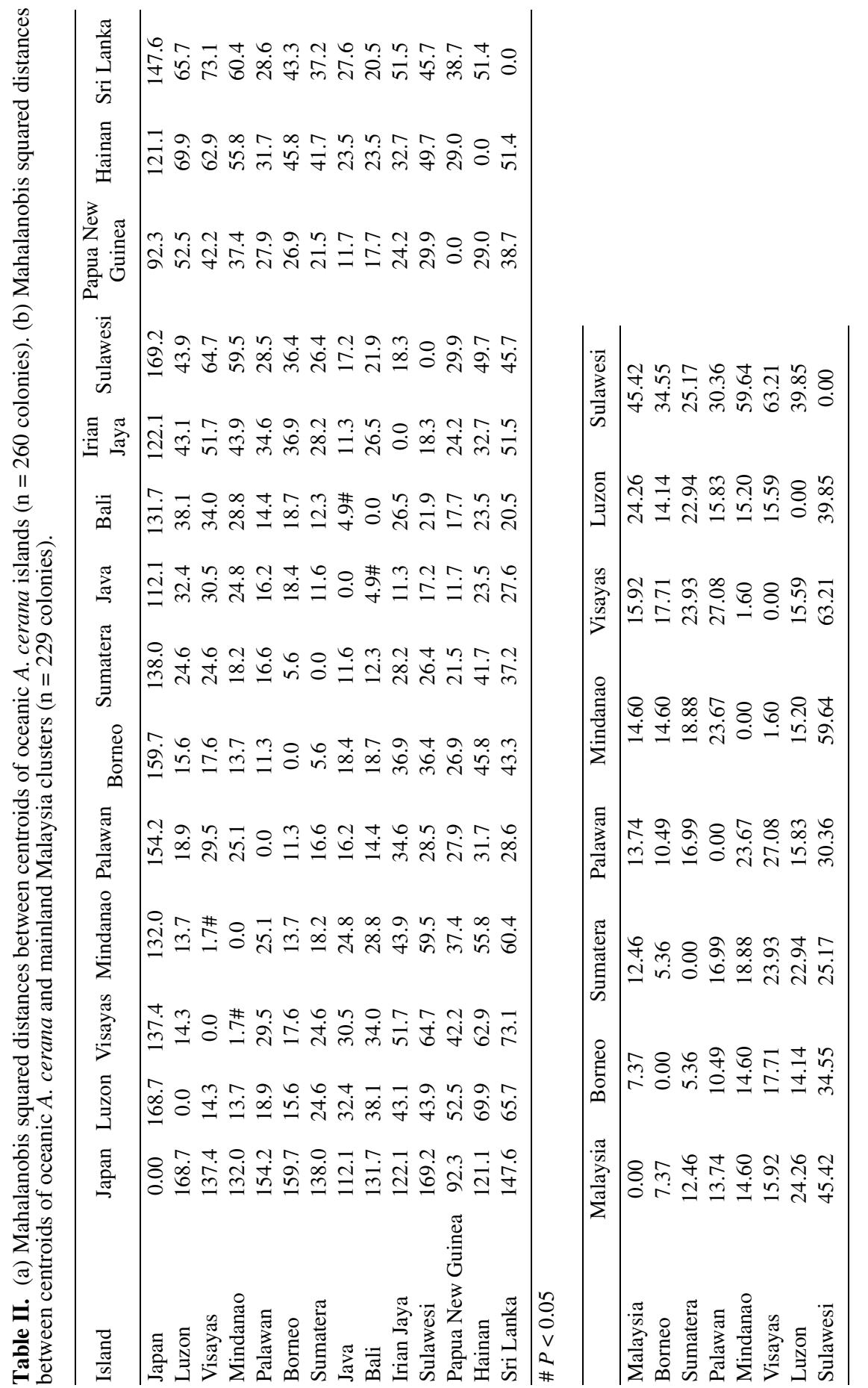


Table III. Means and standard deviations (sd) of 12 morphometric character measurements ( $\mathrm{mm}$ or angles in degrees) and $\mathrm{n}=$ number of colonies for four morphoclusters of A. cerana in oceanic Asia.

\begin{tabular}{|c|c|c|c|c|c|c|c|c|}
\hline & \multicolumn{8}{|c|}{ Morphoclusters } \\
\hline & \multicolumn{2}{|c|}{1} & \multicolumn{2}{|c|}{$2(2.1)$} & \multicolumn{2}{|c|}{$3(2.2)$} & \multicolumn{2}{|c|}{$4(2.3)$} \\
\hline & \multicolumn{2}{|c|}{$\mathrm{n}=8$} & \multicolumn{2}{|c|}{$\mathrm{n}=57$} & \multicolumn{2}{|c|}{$n=119$} & \multicolumn{2}{|c|}{$\mathrm{n}=76$} \\
\hline character & mean & sd & mean & sd & mean & $\mathrm{sd}$ & mean & sd \\
\hline (5) & 2.51 & 0.03 & 2.24 & 0.07 & 2.20 & 0.05 & 2.25 & 0.06 \\
\hline (6) & 3.18 & 0.03 & 2.80 & 0.09 & 2.76 & 0.07 & 2.82 & 0.08 \\
\hline (7) & 1.97 & 0.03 & 1.79 & 0.07 & 1.74 & 0.04 & 1.76 & 0.05 \\
\hline (9) & 2.04 & 0.03 & 1.79 & 0.05 & 1.71 & 0.04 & 1.72 & 0.06 \\
\hline (10) & 1.99 & 0.03 & 1.75 & 0.06 & 1.66 & 0.04 & 1.69 & 0.05 \\
\hline (11) & 2.52 & 0.05 & 2.22 & 0.06 & 2.15 & 0.04 & 2.24 & 0.06 \\
\hline (12) & 1.15 & 0.03 & 0.92 & 0.04 & 0.87 & 0.03 & 0.93 & 0.04 \\
\hline (15) & 2.35 & 0.02 & 2.01 & 0.07 & 2.00 & 0.05 & 2.10 & 0.05 \\
\hline (17) & 8.55 & 0.19 & 7.56 & 0.23 & 7.54 & 0.22 & 7.76 & 0.15 \\
\hline (22) & 113.34 & 2.42 & 102.11 & 2.27 & 104.41 & 2.89 & 108.60 & 2.39 \\
\hline (23) & 93.36 & 1.83 & 96.82 & 1.76 & 97.03 & 1.67 & 96.61 & 1.81 \\
\hline (25) & 89.98 & 0.87 & 89.62 & 2.87 & 90.00 & 1.95 & 92.30 & 2.68 \\
\hline
\end{tabular}

colonies from Santa Cruz (No. 9; Luzon) were classified in cluster 3; colonies from Panado, Samalia and Davao (Nos. 7, 8, 10; Mindanao) were classified in cluster 2; colonies from Palu, Lolu, Rahmat, Kamarora (Nos. 1-4; central Sulawesi) classified in cluster 4 whilst some colonies from Tappalang, Kambuno, Sinjai, Bantaeng, Bulukumba and Jeneponto (Nos. 510; S. Sulawesi) and Purbatongah, Suliki (Nos. 2, 8; Sumatera) classified in clusters 2 or 3 (Tab. I, column G3). The analysis was repeated using 6 characters $((5),(6),(7),(11),(12)$, (17)). This included the Szabo database for Sri Lanka ( $\mathrm{n}=271$ in the analysis) and were again classified in cluster 4 (Tab. I, column G3). Finally, the Japan database from Akahira and Sakagami (1959a, b) was compared with the Japan Oberursal database. No significant differences in the means of the two characters $((6)$, (7)) common to both databases were found between the localities $\left((6): \mathrm{F}_{12,6}=1.34, P=\right.$ 0.3769 ; (7): $\left.\mathrm{F}_{12,6}=1.95, P=0.2120\right)$. The colonies were, therefore, classified into cluster 1 (Tab. I, column G3).

\subsection{Regional microscale analyses within specific island systems}

\subsubsection{Indonesia database}

In an analysis using the Indonesian database alone (57 colonies) with 12 characters, the PC plots of the 1st and the 2nd scores (as well as 1st and 3rd) showed 1 morphocluster with 2 indistinct regional clusters: a group of bees from Sulawesi, Ambon, Lombok and Timor; and, a second group of bees from Java, Bali, Sumbawa and Flores. Colonies from Sumatera and Irian Jaya were in both groups. The first three principal components accounted for $75.8 \%$ of the variation in the data: PC $1,((5)$, (6), (7), (9), (10), (11), (15), (17); 45.8\%); PC 2, ((12), B4, G18; 19.4\%); PC 3, (D7; 10.6\%). The results of an analysis repeated using 6 characters (107 colonies) again yielded 2 indistinct clusters: a group with colonies from $\mathrm{S}$. Sulawesi, Ambon, Lombok and Timor; and, another group from central Sulawesi, Java, Bali, Sumbawa and Flores. Colonies from Sumatera and Irian Jaya were in both groups.

In a separate analysis of the bees from Indonesia which included data from Damus and Otis (1997) from Sulawesi (North: Tahuna, Manado, South: Manipi; 6 colonies), the PC plots of the 1 st and the 2 nd scores using 12 characters showed these bees from Sulawesi $(6 \mathrm{col}-$ onies) to be distinct from those from Sumatera, Java, Bali, Sumbawa, Flores and Irian Jaya (45 colonies). These colonies from Tahuna, Manado and Manipi (Sulawesi) were identified as A. nigrocincta (Damus and Otis, 1997). A kmeans cluster analysis showed $A$. nigrocincta Sulawesi bees to be similar to those from Mindanao, Visayas and Luzon (cluster 2), whilst the $A$. cerana bees from central and southern 
Sulawesi were similar to those from the lesser Sunda islands (clusters 3 and 4).

\subsubsection{Papua New Guinea and Indonesia (Java and Irian Jaya) databases}

A separate analysis of the combined databases for A. cerana of Indonesia (Java and Irian Jaya) from Oberursel, Grahamstown and Sulistianto (1990) and Papua New Guinea from Oberursel (41 colonies) using 12 common characters $((5),(6),(7),(9),(10),(11),(12)$, (15), (17), B4, D7 and G18) was performed. Four eigenvalues greater than one were isolated: PC 1, size related characters ((5), (6), (7), (9), (10), (17) and angle G18 accounted for $47.5 \%$ of the variation; PC 2, size related characters ((11), (12), (15)) accounted for $19.6 \%$ of the variation; PC 3 and PC 4, accounted for a further $17.7 \%$ of the variation. The results of the PC plots yielded 1 morphocluster, with colonies from the three regions intermingled with each other. The squared Mahalanobis distances between the other oceanic islands and Papua New Guinea showed closest morphometric similarity with those of Java $\left(\mathrm{d}^{2}=4.1\right.$, Tab. IIa).

\subsubsection{Philippines database}

Principal components analysis was carried out on the Philippines database alone (124 colonies) using twelve morphometric characters. Four principal components with eigenvalues greater than one were isolated: PC 1 , sizerelated characters (5), (6), (7), (9), (10), (11), (12), (15) and (17) and accounted for $43.2 \%$ of the variation; PC 2, angle of venation B4 and accounted for $15.5 \%$ of the variation; PC 3, angle of venation G18 and accounted for $10.0 \%$ of the variation; PC 4, angle of venation D7 and accounted for a further $9.1 \%$ of the variation. The four principal components accounted for a total of $77.7 \%$ of the variation in the data. The PC plot of the 1st and 2nd scores revealed one morphocluster with three indistinct clusters of bees from (1) Palawan, (2) Luzon, and (3) Visayas and Mindanao.

\subsection{Specific mainland/island "interfaces" analyses}

\subsubsection{S. India and Sri Lanka databases}

A separate analysis of the combined databases for A. cerana of S. India (Oberursel) and Sri Lanka (Oberursel and Grahamstown, 65 colonies) using 12 common characters $((5),(6)$, (7), (9), (10), (11), (12), (15), (17), B4, D7 and G18) was performed. Four eigenvalues greater than one were isolated: PC 1, size related characters (5), (6), (7), (9), (10), (11), (17) accounted for $44.6 \%$ of the variation; PC 2 , (12), angle of venation D7 (23) accounted for $15.6 \%$ of the variation; PC 3, (15), angle of venation G18 (25) accounted for $12.7 \%$ of the variation and PC 4, angle of venation B4 (22) accounted for a further $8.4 \%$ of the variation The four principal components accounted for a total of $81.2 \%$ of the variation in the data. The results of the $\mathrm{PC}$ plots showed 1 morphocluster, with PC scores of colonies from Sri Lanka intermingled with those from localities Bangarapet, Bangalore, Yarakapadi and Kanyakumari (S. India). The squared Mahalanobis distances between Sri Lanka, S. India and N. India clusters revealed closer similarity between Sri Lanka and S. India $\left(d^{2}=9.1\right)$ than N. India $\left(d^{2}=24.3\right)$.

\subsubsection{Indonesia-Borneo-Philippines and southeast Asia mainland databases}

Databases for A. cerana of Indonesia, Malaysia (N. Borneo), Philippines were combined with those of Malaysia (Peninsular) and Vietnam (290 colonies). PC results using 12 common characters revealed that the bees from the Indonesia-Borneo-Philippines group of islands are indistinct from those of mainland Malaysia, whilst distinct from those of Vietnam. The first two principal components accounted for $67.5 \%$ of the variation in the data: PC 1, ((5), (6), (7), (9), (10), (11), (12), (15), (17); 56.8\%); PC 2, (B4 (22), G18 (25); $10.7 \%$ ). Table IIb gives the squared Mahalanobis distances between Borneo, Sumatera, Palawan, Mindanao, Visayas, Luzon, Sulawesi and mainland Malaysia. Closer similarity is seen between Borneo $\left(\mathrm{d}^{2}=7.4\right)$, Sumatera $\left(\mathrm{d}^{2}=\right.$ 12.4) and Palawan $\left(\mathrm{d}^{2}=13.7\right)$ and mainland 
Malaysia than between Sulawesi and the other Philippine islands.

\subsubsection{Hainan and China databases}

Databases (Kunming) for A. cerana of Hainan were combined with those of S. China (Guangxi, Guangdong, Yunnan Provinces), N. China (Beijing and Jilin Province) and Hong Kong (Grahamstown database; $\mathrm{n}=54$ colonies). PC results using 12 common characters revealed that the bees from Hainan are indistinct from those of southern China (Guangxi, Guangdong, S. Yunnan Provinces), whilst distinct from those of Hong Kong, N. Yunnan and N. China. The first two principal components accounted for $70.0 \%$ of the variation in the data: PC 1, ((5), (6), (7), (9), (10), (11), (12), (15), (17); 59.7\%); PC 2, (B4 (22), D7 (23), G18 (25); 10.3\%). Table IIc gives the squared Mahalanobis distances between Hainan and mainland S. China (Guangxi, Guangdong), S. Yunnan, N. Yunnan, Hong Kong and N. China. Closer similarity is seen between S. China (Guangxi, Guangdong) $\left(\mathrm{d}^{2}=36.1\right)$, S. Yunnan $\left(d^{2}=39.8\right)$ and Hainan than between N. Yunnan, Hong Kong and N. China $\left(\mathrm{d}^{2}>51.3\right)$.

\subsubsection{Japan and Korea databases}

In an analysis using Japan and Korea (Seoul) data from Oberursel (13 colonies), the PC results using 12 characters showed 2 distinct morphoclusters: a group of bees from Tokyo and Izuhara (Japan, Nos. 1, 4); and, a second group of bees from Korea. Colonies from Fukuoka and Yamanashi (Japan, Nos. 2, 3) were not included in the two groups. The first two principal components accounted for $74.5 \%$ of the variation in the data: PC $1,((6),(7),(9),(11)$, (12), (15), (17), B4 (22); 47.0\%); PC 2, ((5), (10), G18 (25); 27.5\%).

\section{DISCUSSION}

\subsection{Mesoscale analysis}

The principal component analysis and kernel density plots of the total oceanic database on a mesoscale level yielded two distinct morphoclusters at the same level of cluster discrimination: morphocluster 1, the bees of Japan and morphocluster 2, the bees of all the other islands. Within morphocluster 2 three indistinct and overlapping regional clusters were observed: 2.1 the bees of the Philippines (except Palawan), Sumbawa and Flores (Indonesia), 2.2 Palawan, Malaysian Borneo, and, some Sumatera, Kalimantan, S. Sulawesi, Lombok and Timor (Indonesia), and 2.3 most of Indonesia, Papua New Guinea, Hainan and Sri Lanka. Significant differences between the means of the four groups were demonstrated using Wilks' lambda statistic.

The results of the two other mesoscale analyses of oceanic $A$. cerana must be considered. Firstly, the results Ruttner (1988), based on fewer samples from fewer of the oceanic countries, are nonetheless consistent with ours in general terms: the morphometric separation of bees from Japan, Vietnam, Sumatera, Sri Lanka and the Philippines (but not S. India). The analyses of Damus and Otis (1997) share similarities with our results, but also differ in that the bees of Japan, the Philippines, Sri Lanka and Indonesia (Java) and Indonesia (Sulawesi) as well Indonesia (Timor) could be distinguished morphometrically. Given considerable variation in honeybee specimen, locality sample sizes and differences in morphological character suites, the results of Ruttner (1988) and Damus and Otis (1997) are generally consistent with those obtained from the much enlarged database presented here.

\subsection{Microscale analyses}

Morphometrical differences on a geographical microscale could occur within particular islands systems but may be obscured in large mesoscale analyses for statistical reasons (Radloff and Hepburn, 1998). Indeed this is confirmed for oceanic A. cerana as well. The series of separate "within-island" analyses (using 6 characters) demonstrated that the bees of S. Sulawesi, Timor, Lombok and Ambon formed one group and central Sulawesi, Java, Bali, Sumbawa and Flores a second "within Indonesia" group. In the Philippines, three "within island" groups were discernible: (1) Palawan, (2) Luzon and (3) the Visayas and Mindanao, results consistent with the "within Philippines" results of Tilde et al. (2000). The Indonesia-Papua New Guinea comparison is of particular interest because A. cerana were 
introduced into Papua New Guinea from a single apiary in Java in 1977 (D. Anderson, Canberra, Australia, pers. comm.). These introduced bees are indistinguishable from the original population and represent a founder effect as the population spreads in Irian Jaya and Papua New Guinea.

In one of the analyses of the Indonesian bees, colonies from Tahuna, Manado and Manipi (Sulawesi) formed a distinctly different group than those from central and south of the island. However, it now appears that these bees, named A. nigrocincta by Damus and Otis (1997) and also recognized as a probably good species by Engel (1999), may well be a very recently derived offshoot of $A$. cerana. If it were not for differences in the timing of mating flights with sympatric $A$. cerana (Hadisoesilo and Otis, 1996) and the lack of a pore in the cappings of drone cells (Hadisoesilo and Otis, 1998), "A. nigrocincta" might otherwise be considered a "subspecies" of A. cerana. Additional light is shed by mtDNA analyses, which show that, when the haplotypes of the Indonesia-Philippines region are graphed in a neighbour-joining tree, some samples of bees from Sulawesi (e.g. from N. Sulawesi) are intermediate between the A. cerana of both island groups (Smith et al., 2000, 2003; Takahashi et al., 2002). This intermediate mtDNA status for Sulawesi is reflected in the earlier ideas that the "A. cerana" of South Sulawesi were a separate subspecies of $A$. cerana (Hadisoesilo et al., 1995; Hadisoesilo, 1997; Damus and Otis, 1997). Indeed, the Mahalanobis distances between the "A. nigrocincta" bees of $\mathrm{N}$. Sulawesi is smallest with the Visayas and Mindanao to the north (19.9 and 22.3 respectively) and twice that with A. cerana of Java, Sumatera and Borneo (51.0, 49.9 and 40.9, respectively). This topic will be further explored in another study.

\subsection{Island-mainland interface analyses}

Measurements of morphometric distances between groups allow an assessment of whether bees could have moved from the mainland to the island in a stepping stone manner. There may also be indications of homeomorphy that represent bottleneck populations. Sri Lanka and India are just barely separated $(<1 \mathrm{~km})$ by the Palk Strait, but there are many stepping stone islands between them. The morphometric analyses showed that the bees from the island and mainland to be indistinguishable. Moreover, when the bees of northern and southern India were combined with those of Sri Lanka, the Mahalanobis distances between them established a considerably greater affinity between the A. cerana of S. India and Sri Lanka than either share with N. India. When the databases of the Indonesia, Malaysia and the Philippines were compared it emerged that the Mahalanobis distance values increased with increasing geographical distance (Tab. IIb). Mainland Malaysia is barely separated from Sumatera by the Malacca Strait, which contains many small stepping-stone islands between the two, but Borneo is about $500 \mathrm{~km}$ away from both the Malay Peninsula and Sumatera. Similarly, the bees of Hainan Island were found to be similar to those of southern China. Here too distances are small, the mainland is separated from Hainan by the Selat Hainan, which is less than $30 \mathrm{~km}$ wide. Finally, the analyses of the bees of Japan and Korea showed the bees to differ significantly, confirming earlier results to the same effect (Ruttner, 1988; Damus and Otis, 1997). The Strait of Korea separates the two by some $150 \mathrm{~km}$ and there are few intervening islands except for Tsushima.

It is pertinent to consider the nature of $A$. cerana populations of the islands close to mainland Asia in the context of both present sea levels, their extent and duration in the recent Pleistocene (250 000 years BP). This allows some insight as to possible paths, possibilities and duration of genetic flow between these populations (Tab. IIb). In a comprehensive analysis of sea level changes in Southeast Asia during the Pleistocene, Voris (2000) demonstrated that most of the present land areas considered here, either in or bounded by the South China, Java, Andaman seas have undergone major cyclical changes with rises and falls of sea level. The depths of the sea surrounding these areas are less than $40 \mathrm{~m}$ today. For 110000 of the last 250000 years (middle Pleistocene, Gradstein et al., 2004), the seas of this region were dry land; and, during the last 17 000 years was dry land for 11000 years (Voris, 2000). Thus, it seems probable that $A$. cerana expanded as a contiguous population within these Pleistocene time windows between continental mainland and island systems close by. 
Moreover, the increases in Mahalanobis values with increasing distance of islands-to-mainland are consistent with the morphometric similarities and differences relative to land surface area changes over time.

At the same time, it should also be noted that A. cerana also occurs in the Andaman and Nicobar Islands situated some $300 \mathrm{~km}$ distant from southwestern Myanmar on the far side of the deeply trenched Andaman Basin. There is also deep water between Bali and Lombok, Sawu, Timor and Sumba, and Palawan and the other islands of the Philippines but A.cerana occurs on all of them. A. cerana was reportedly introduced into Ambon, and possibly Ceram, (Maa, 1953), and both of these islands were also always separated from Sulawesi to the west during the Pleistocene period. Although no information is available on the occurrence of A. cerana in the chain of islands Pulau Simeulue, Pulau Nias, Kepulauan Mentawai and Pulau Enggano, (flanking the southwestern side of Sumatera) this chain has also been separated by a deep trench from the latter. Fluctuations in the sea level during the Pleistocene do not afford a land bridge explanation for the occurrence of bees on these islands. It is to be hoped that mtDNA analyses will eventually shed more light on the affinities of $A$. cerana occurring on these islands isolated from most others throughout the Pleistocene.

\section{ACKNOWLEDGEMENTS}

We are grateful to D. Anderson for technical information.

Résumé - Analyse morphométrique multivariée des populations d'Apis cerana d'Âsie océanique. Des analyses morphométriques multivariées ont été faites sur 5310 ouvrières d'abeilles (Apis cerana Fabr.) représentant 346 colonies réparties en 123 localités de l'Asie océanique. La base de données d'Oberursel pour A. cerana a fourni des données déjà analysées. Du matériel nouveau provenant d'Indonésie, du nord de Bornéo (Malaisie), de Papouasie Nouvelle Guinée, des Philippines, du Sri Lanka et de Hainan (Chine) a fourni de nouvelles données (Tab. I, Fig. 1). Les mesures ayant été faites par diverses personnes, ces valeurs ont été ajustées par rapport à la base de données d'Oberursel en prenant des paires de mesures pour les mêmes localités et en les ajustant en conséquence.
Une analyse à échelle moyenne a été faite sur tout le groupe océanique et des analyses à petite échelle au sein des systèmes insulaires spécifiques. Les « interfaces » continent-îles océaniques ont été analysées. L'analyse en composantes principales de la base de données océanique complète au niveau de l'échelle moyenne a fourni deux groupes morphologiques (« morphocluster ») distincts : (1) les abeilles du Japon, (2) les abeilles de toutes les autres îles. Les analyses discriminantes et les analyses de groupement hiérarchique ont montré trois groupes régionaux indistincts se chevauchant au sein du groupe morphologique $2: 2.1$ les abeilles des Philippines (sauf Palawan) et d'une partie de l'Indonésie, 2.2 les abeilles de Palawan, de la partie malaisienne de Bornéo, du Kalimantan, de Sumatra et d'une partie du Sulawesi (Indonésie); et 2.3 la plus grande partie de l'Indonésie, la Papouasie Nouvelle-Guinée, Hainan (Chine) et Sri Lanka. Le test statistique de Wilks lambda a montré des différences significatives entre les moyennes des quatre groupes. Les distances de Mahalanobis entre les échantillons d'abeilles sont cohérentes avec les hausses et les baisses cycliques du niveau des mers entre les surfaces émergées du présent et du Pléistocène (Tab. IIa).

Les séries d'analyses individuelles au sein du système insulaire montrent que les abeilles du sud du Sulawesi, de Timor, Lombok et Ambon forment un groupe et celles du centre du Sulawesi, de Java, Bali, Sumbawa et Flores un second groupe à l'intérieur du groupe Indonésie. La comparaison des distances de Mahalanobis au carré entre les populations des autres îles océaniques et de la Papouasie Nouvelle Guinée montre une similitude morphométrique plus étroite avec qu'avec celles de Java $\left(\mathrm{d}^{2}=4,1\right.$, Tab. IIa). Ce résultat est particulièrement intéressant parce que A. cerana a été introduite en Papouasie Nouvelle Guinée à partir d'un seul rucher de Java en 1977 (D. Anderson, communication personnelle). Aux Philippines, les trois groupes du « système insulaire» sont discernables : (1) Palawan, (2) Luzon et (3) Visayas et Mindanao, résultat cohérent avec ceux de Tilde et al. (2000).

Les séries d'analyses des « interfaces » continent îles océaniques montrent : (1) une affinité bien plus grande entre les population d'A. cerana du sud de l'Inde et celles de Sri Lanka qu'avec celles du nord de l'Inde ; (2) que les abeilles du groupe d'îles Indonésie-Bornéo-Philippines ne se distinguent pas de celle de Malaisie continentale, alors qu'elles sont distinctes de celles du Vietnam. On observe une similitude plus étroite entre Bornéo $\left(\mathrm{d}^{2}=7,4\right)$, Sumatra $\left(d^{2}=12,4\right)$ et Palawan $\left(d^{2}=13,7\right)$ et la Malaisie continentale qu'entre Sulawesi et les autres îles des Philippines (Tab. III) ; (3) les abeilles de l'île d'Hainan sont semblables à celles de la Chine méridionale (Tab. IIc) ; (4) finalement, les abeilles du Japon et de Corée sont significativement différentes, ce qui confirme les résultats antérieurs (Ruttner, 1988 ; Damus et Otis, 1997).

Apis cerana / morphométrie / biogéographie / îles 
Zusammenfassung - Multivariate morphometrische Analyse der Populationen von Apis cerana des ozeanischen Asien. Insgesamt 5310 Bienenarbeiterinnen von Apis cerana wurden einer multivariaten morphometrischen Analyse unterzogen, diese repräsentierten 346 Völker von 123 über das ganze ozeanische Asien verteilte Herkunftsorte. Die Daten schließen neues Material aus Indonesien, Nordborneo (Malaysia), Papua Neuguinea, den Philippinen, Sri Lanka und Hainan (China) sowie bereits zuvor analysierte überwiegend der Oberurseler Datenbank über A. cerana entstammende Daten ein (Tab. I, Abb. 1). Da verschiedene Personen die Messungen durchgeführt hatten, wurden sie anhand von Messungen an Proben gleicher Herkunft mit der Oberurseler Datenbank abgeglichen.

Die gesamte ozeanische Gruppe wurde in einer Analyse auf mittlerem Skalierungsniveau untersucht, für spezifische Inselsysteme wurde diese dann durch eine feinskalierte Analyse ergänzt. Darüber hinaus wurden spezifische Übergangszonen zwischen dem Festland und den ozeanischen Inseln getrennt analysiert. Die Hauptkomponentenanalyse des gesamten ozeanischen Datenbestandes auf mittelskaliertem Niveau zeigte zwei getrennte Hauptkluster, von denen Morphokluster 1 die Bienen Japans enthielt, während die Bienen aller anderen Inseln in den Morphokluster 2 fielen. Innerhalb des Morphokluster 2 zeigten sich in einer Diskriminanzanalyse in Kombination mit einer Klusteranalyse drei überlappende regionale Kluster. Kluster 2.1 enthielt die Bienen der Philippinen außer Palawan sowie einige Proben von Indonesien; Kluster 2.2 die Bienen von Palawan, dem malaischen Teil von Borneo, Kalimantan, Sumatra und einige Proben von Sulawesi; Kluster 2.3 schloss den größten Teil von Indonesien, Papua Neu Guinea, Hainan (China) und Sri Lanka ein. Zwischen den Mittelwerten der 4 Gruppen wurden anhand einer Wilks' Lambda Statistik signifikante Unterschiede nachgewiesen. Die Mahalanobisabstände zwischen den Bienenproben sind mit den geografischen Veränderungen durch zyklische geologische Anhebungen und Absenkungen der Meereshöhe zwischen dem Pleistozän und der Gegenwart konsistent (Tab. IIa).

Die Reihe von Einzelanalysen innerhalb von Inselsystemen zeigte, dass die Bienen von Südsulawesi, Timor, Lombok und Ambon eine, die von Zentralsulawesi, Java, Bali, Sumbawa und Flores eine zweite Gruppe innerhalb der „Indonesien“ Gruppe bildeten. Das Ergebnis des Vergleichs der quadrierten Mahalanobisdistanzen zwischen Papua Neuguinea und Indonesien sowie zu den anderen ozeanischen Inseln zeigte die größte morphometrische Ähnlichkeit mit denen von Java $\left(\mathrm{d}^{2}=4,1\right.$, Tab. IIa). Dies ist interessant, da A. cerana erst 1977 von einem einzelnen Bienenstand in Java nach Papua Neuguinea eingeführt worden war (D. Anderson, Canberra, Australien, pers. Mitteilung). In den Philippinen waren drei ,Inselsystem“ Gruppen unterscheidbar: (1) Palawan, (2) Luzon und (3) Visayas und Minda- nao. Diese Ergebnisse stimmen mit der Analyse von Tilde et al. (2000) überein.

Die Reihe von Einzelanalysen von Festland - Insel Übergängen zeigte (1) eine deutlich größere Nähe zwischen A. cerana von Südindien und Sri Lanka als mit Nordindien; (2) die Bienen der Inseln von Indonesia, Borneo und den Philippinen sind nicht unterschiedlich von denen des malaiischen Festlands, aber deutlich unterschiedlich von den Bienen Vietnams. Hierbei zeigten sich die Bienen von Borneo $\left(d^{2}=7,4\right)$, Sumatra $\left(d^{2}=12,4\right)$ Palawan $\left(d^{2}=13,7\right)$ ähnlicher mit denen des malaiischen Festlands als die Philippinischen Inseln zu Sulawesi (Tab. IIb); (3) die Bienen der Insel Hainan zeigten sich ähnlich zu denen des südlichen China (Tab. IIc); (4) die Bienen von Japan waren deutlich von denen Koreas unterschiedlich, dies stimmt mit dem Ergebnis früherer Analysen von Ruttner (1988) und Damus und Otis (1997) überein.

\section{Apis cerana / Morphometrie / Biographie / Inseln}

\section{REFERENCES}

Akahira Y. Sakagami S.F. (1959a) Notes of the difference in some external characteristics between Japanese (A. cerana cerana) and European honeybees (A. m. ligustica), Annotat. Zool. Jap. 32, 35-42.

Akahira Y., Sakagami S.F. (1959b) A biometrical study on the Japanese honey bee, observations upon some populations of Kyushu, J. Hokkaido Gakugei Univ. 14, 175-184.

Daly H.V., Balling S.S. (1978) Identification of Africanized honeybees in the western hemisphere by discriminant analysis, J. Kans. Entomol. Soc. $51,857-869$.

Damus M.S. (1995) A morphometric and genetic analysis of honey bee (Apis cerana F.) samples from Malesia: population discrimination and relationships, Thesis, University of Guelph, Guelph, Ontario.

Damus M.S., Otis G.W. (1997) A morphometric analysis of Apis cerana F. and Apis nigrocincta Smith populations from southeast Asia, Apidologie 28, 309-323.

DuPraw E.J. (1964) Non-Linnean taxonomy, Nature 202, 849-852.

Enderlein G. (1906) New honeybees and contribution to the distribution of the genus Apis, Stett. Entomol. Ztg. 67, 331-334 (in German).

Engel M.S. (1999) The taxonomy of recent and fossil honey bees (Hymenoptera: Apidae; Apis), J. Hymenoptera Res. 8, 165-196.

Fabricius J.C. (1793) Mantissa Insectorum, Hafniae, Proft. Vol. 1, p. 348 (cited from Maa, 1953).

Fernando E.F.W. (1979) Some biometrical features of Apis cerana F. from Sri Lanka, Indian Bee J. 41, 5-8.

Gerstäcker C.E.A. (1863) On the geographical distribution of honeybees, Ann. Mag. Nat. Hist. London 11, 270-283; 333-347. 
Gradstein F.M., Ogg J.G., Smith A.G., Bleeker W., Lourens L.J. (2004) A new geologic time scale, with special reference to Precambrian and Neogene, Episodes 27, 83-100.

Hadisoesilo S. (1997) A comparative study of two species of cavity-nesting honey bees of Sulawesi Indonesia, $\mathrm{PhD}$ Dissertation, University of Guelph, Guelph, Ontario, Canada, pp. 1-199.

Hadisoesilo S., Otis G.W. (1996) Drone flight times confirm the species status of Apis nigrocincta Smith, 1861 to be a species distinct from Apis cerana F., 1793, in Sulawesi, Indonesia, Apidologie 27, 361-369.

Hadisoesilo S., Otis G.W. (1998) Differences in drone cappings of Apis cerana and Apis nigrocincta, J. Apic. Res. 37, 11-15.

Hadisoesilo S., Otis G.W., Meixner M. (1995) Two distinct populations of cavity-nesting honey bees (Hymenoptera: Apidae) in South Sulawesi, Indonesia, J. Kans. Entomol. Soc. 68, 399-407.

Hepburn H.R., Smith D.R., Radloff S.E., Otis G.W. (2001a) Infraspecific categories of Apis cerana: morphometric, allozymal and mtDNA diversity, Apidologie 32, 3-23.

Hepburn H.R., Radloff S.E., Verma S., Verma L.R (2001b) Morphometric analysis of Apis cerana populations in the southern Himalayan region, Apidologie 32, 435-447.

Horne C., Smith F. (1872) Notes on the habits of some hymenopterous insects from the north-west provinces of India, Trans. Zool. Soc. London 7, 161-185.

Johnson R.A., Wichern D.W. (1998) Applied Multivariate Statistical Analysis, 4th ed., Prentice Hall, Upper Saddle River, New Jersey.

Ken T., Fuchs S., Koeniger N., Ruiguang Z. (2003) Morphological characterization of Apis cerana in the Yunnan Province of China, Apidologie 34, 553-562.

Maa T. (1953) An enquiry into the systematics of the tribus Apidini or honey bees (Hymenoptera), Treubia 21, 525-640.

Moore F., Walker F., Smith F. (1871) Descriptions of some new insects collected by Dr Anderson during the expedition to Yunnan, Proc. Zool. Soc. London, 244-249.

Quinn G.P., Keough M.J. (2002) Experimental Design and Data Analysis for Biologists, Cambridge University Press, Cambridge.

Radloff S.E., Hepburn H.R. (1998) The matter of sampling distance and confidence levels in the subspecific classification of honeybees, Apis mellifera L., Apidologie 29, 491-501.

Radloff S.E., Hepburn H.R., Fuchs S. (2005a) The morphometric affinities of Apis cerana of the Hindu Kush and Himalayan regions of western Asia, Apidologie 36, 25-30.
Radloff S.E., Hepburn H.R., Hepburn C., Fuchs S. Otis G.W., Sein M.M., Aung H.L., Pham H.T., Tam D.Q., Nuru A.M., Ken T. (2005b) Multivariate morphometric analysis of Apis cerana of southern mainland Asia, Apidologie $36,127-139$

Rao P.V. (1998) Statistical Research Methods in Life Sciences, Brooks/Cole Publishing Company, Pacific Grove, CA.

Rinderer T.E., Koeniger N., Tingek S., Mardan M., Koeniger G. (1989) A morphological comparison of the cavity dwelling honeybees of Borneo Apis koschevnikovi (von Buttel-Reepen, 1906) and Apis cerana (Fabricius, 1793), Apidologie 20, 405-411.

Ruttner F. (1985) Characteristics and variability of Apis cerana (Fabr.) Proc. XXXth Int. Congr. Apic., Nagoya, Apimondia, pp. 130-133.

Ruttner F. (1988) Biogeography and Taxonomy of Honeybees, Springer-Verlag, Berlin.

Ruttner F., Tassencourt L., Louveaux J. (1978) Biometrical-statistical analysis of the geographical variability of Apis mellifera L., Apidologie 9, 363381.

Smith D.R., Villafuerte L., Otis G.W., Palmer M.R. (2000) Biogeography of Apis cerana F. and A. nigrocincta Smith: Insights from mtDNA studies, Apidologie 31, 265-280.

Smith D.R. Palmer M.R Otis G.W Damus MS. (2003) Mitochondrial DNA and AFLP markers support species status of Apis nigrocincta, Insectes Soc. 50, 185-190.

Smith F. (1871) Catalogue of the aculeate Hymenoptera and Ichneumonidae of India and the eastern archipelago, J. Linn. Soc.11, 285-414.

Sulistianto A. (1990) Morphometric Analysis of Indonesian Honeybees, MSc Thesis, 85 p.

Szabo T.I. (1990) Morphometric characteristics of Apis cerana from Sri Lanka, Apidologie 21, 505-509.

Takahashi J., Nakamura J., Sasaki M., Tingek S., Akimoto S.I. (2002) New haplotypes for the noncoding region of mitochondrial DNA in cavitynesting honey bees Apis koschevnikovi and Apis nuluensis, Apidologie 33, 25-31.

Tilde A.C., Fuchs S., Koeniger N., Cervancia C.R. (2000) Morphometric diversity of Apis cerana Fabr. within the Philippines, Apidologie 31, 249264.

von Buttel-Reepen H. (1906) Contributions to the systematics, biology as well as the historical and geographical distribution of honeybees (Apis mellifica L.) their variability and other Apis species, Mitt. Zool. Mus. Berl. 3, 117-201 (in German).

Voris H.K. (2000) Maps of Pleistocene sea levels in Southeast Asia: shorelines, river systems and time durations, J. Biogeogr. 27, 11531167. 